This is a self-archived version of an original article. This version may differ from the original in pagination and typographic details.

Author(s): Djemili, Ryan; Kocher, Lucas; Durot, Stéphanie; Peuronen, Anssi; Rissanen, Kari;
Heitz, Valérie

Title: Positive Allosteric Control of Guests Encapsulation by Metal Binding to Covalent Porphyrin Cages

Year: 2019

Version: Accepted version (Final draft)

Copyright: @ 2019 Wiley-VCH Verlag GmbH \& Co.

Rights: In Copyright

Rights url: http://rightsstatements.org/page//nC/1.0/?language=en

Please cite the original version:

Djemili, R., Kocher, L., Durot, S., Peuronen, A., Rissanen, K., \& Heitz, V. (2019). Positive Allosteric Control of Guests Encapsulation by Metal Binding to Covalent Porphyrin Cages. Chemistry: A European Journal, 25(6), 1481-1487. https://doi.org/10.1002/chem.201805498 


\section{CHEMISTRY A European Journal}

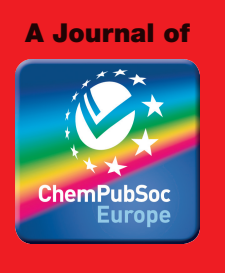

\section{Accepted Article}

Title: Positive Allosteric Control of Guests Encapsulation by Metal Binding to Covalent Porphyrin Cages

Authors: Ryan Djemili, Lucas Kocher, Stéphanie Durot, Anssi Peuroren, Kari Rissanen, and Valérie Heitz

This manuscript has been accepted after peer review and appears as an Accepted Article online prior to editing, proofing, and formal publication of the final Version of Record (VoR). This work is currently citable by using the Digital Object Identifier (DOI) given below. The VoR will be published online in Early View as soon as possible and may be different to this Accepted Article as a result of editing. Readers should obtain the VoR from the journal website shown below when it is published to ensure accuracy of information. The authors are responsible for the content of this Accepted Article.

To be cited as: Chem. Eur. J. 10.1002/chem.201805498

Link to VoR: http://dx.doi.org/10.1002/chem.201805498 
WILEY-VCH

\title{
Positive Allosteric Control of Guests Encapsulation by Metal Binding to Covalent Porphyrin Cages
}

\author{
Ryan Djemili, ${ }^{[a]}$ Lucas Kocher, ${ }^{[a]}$ Stéphanie Durot, ${ }^{[a]}$ Anssi Peuronen, ${ }^{[b]}$ Kari Rissanen, ${ }^{[c]}$ and Valérie \\ Heitz $^{*[a]}$
}

\begin{abstract}
The allosteric control of the receptor property of two flexible covalent cages is reported. These receptors consist of two zinc(II) porphyrins connected by four linkers of two different sizes, each incorporating two 1,2,3-triazolyl ligands. Silver(I) ions act as an effector, responsible for an on/off encapsulation mechanism of neutral guest molecules. Binding silver(l) ions to the triazoles opens the cages and triggers the coordination of pyrazine or the encapsulation of N,N'-dibutyl-1,4,5,8-naphthalene diimide. The X-ray structure of the silver(I)-complexed receptor with short connectors is reported, revealing the hollow structure with a cavity well-defined by two eclipsed porphyrins. Rather unexpectedly, the crystallographic structure of this receptor with pyrazine as guest shows that the cavity is occupied with two pyrazines, each binding to the zinc(II) porphyrin in a monotopic fashion.
\end{abstract}

\section{Introduction}

Allostery is one of the most important regulatory mechanism of protein activity. It is associated to a great diversity of cellular processes and involves a binding event at a specific site to trigger an action at a remote site. ${ }^{[1]}$ Hemoglobin is a tetrameric protein considered as the allosteric protein archetype displaying a cooperative homotropic binding of four dioxygen molecules. Many more complex multidomain regulatory proteins and biological machines that integrate multiple signaling events and long-range coupled conformational modifications through homotropic or heterotropic binding events have shown to proceed also through allosteric mechanisms. ${ }^{[2,3]}$ Whereas the design of $3 \mathrm{D}$ hollow structures has led to selective receptors for guest encapsulation and promising molecular nanoreactors, ${ }^{[4-24]}$ their development as biomimetic allosteric receptors able to control guest complexation through large conformational changes remains a significant challenge. ${ }^{[25-32]}$ Such control implies to integrate in the framework of the structure several components with defined regulation and

\footnotetext{
[a] R. Djemili, Dr. L. Kocher, Dr. S. Durot, Prof. V. Heitz Laboratoire de Synthèse des Assemblages Moléculaires et Multifonctionnels,

Institut de Chimie de Strasbourg, CNRS/UMR 7177, Université de Strasbourg, 4, rue Blaise Pascal, 67000 Strasbourg (France) E-mail:v.heitz@unistra.fr

[b] Dr. A. Peuronen, Inorganic Materials Chemistry Research Group, Laboratory of Materials Chemistry and Chemical Analysis, Department of Chemistry, University of Turku, 20014 Turku, Finland

[c] Prof. K. Rissanen,

University of Jyvaskyla, Department of Chemistry,

40014 Jyväskylä (Finland)

E-mail: kari.t.rissanen@jyu.fi
}

guest binding functions. Moreover, the structure must ensure the preorganization of the active components, the flexibility for conformational rearrangements and should prevent direct interactions between the recognition and regulation sites.

Promising allosteric modulation of the receptor activity of multicomponent 3D containers has been obtained using chemical, ${ }^{[33-}$ 48] redox, ${ }^{[49-51]}$ or photoinduced reactions. ${ }^{\left[{ }^{[52-58]}\right.}$ Most of such structures are self-assembled using hydrogen or metal-ligand bonds, but covalent structures remain interesting for their high chemical stability and their ability to respond to various signaling events. Porphyrins are attractive as active components for artificial allosteric systems due to their involvements in many biological processes through their binding, redox or photophysical properties. Especially, structures incorporating metalloporphyrins with a defined binding pocket have shown molecular recognition properties and catalytic activity. ${ }^{[11,59-75]}$

Our previous work has focused on the synthesis of coordination ${ }^{[76]}$ and covalent architectures incorporating metalloporphyrins. ${ }^{[7-79]}$ In particular, flexible covalent cages incorporating orthogonal binding sites, metalloporphyrins and 1,2,3-triazoles, were obtained using a DABCO-templated copper(I)-catalyzed alkyneazide reaction (DABCO: 1,4-diazabicyclo[2.2.2]octane). This templated synthesis enabled to perform simultaneously the macrocyclization reaction as well as the synthesis of four out of eight triazole ligands of the structure, limiting therefore the synthetic effort to obtain these molecules. ${ }^{[78,79]}$ Protonation of both the porphyrins and the triazoles in the cages with two free-base porphyrins was shown to inflate the structures. ${ }^{[9]}$ Moreover, a controlled-breathing of the cage with reversible binding of silver(I) ions to the peripheral triazoles was shown to operate with both the free-base and zinc(II)-metalated porphyrins (Scheme 1).

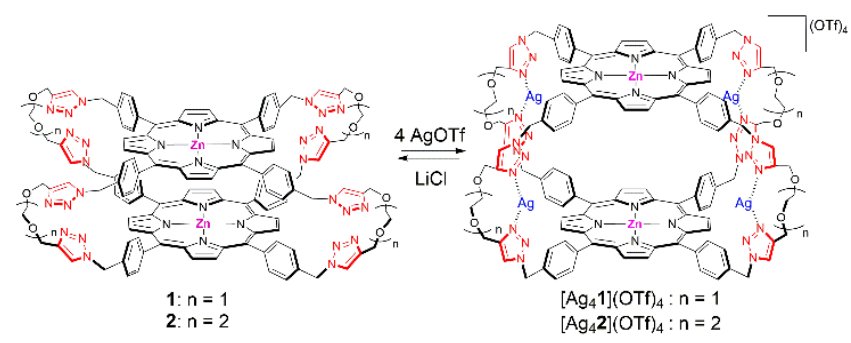

Scheme 1. Breathing motion of flexible zinc(II) porphyrin cages by reversible binding of silver(I) ions to the peripheral triazoles.

Herein, the allosteric control of the receptor properties of the molecular structures $\mathbf{1}$ and $\mathbf{2}$ is investigated. It is shown that silver(I) ions act as a chemical effector that triggers upon binding to the cages, the encapsulation of neutral guest molecules. 
Thanks to the chemical nature of the zinc(II) porphyrins, the allosteric mechanism is shown to operate both for a ditopic ligand, pyrazine, and for a flat aromatic guest, N,N'-dibutyl-1,4,5,8naphthalene diimide (NDI). The X-ray structural analyses confirmed the open structure of silver(I)-complexed cage 1 as well as the encapsulation of pyrazine in this receptor

\section{Results and Discussion}

\section{X-ray structure of $\left[\mathrm{Ag}_{4} 1\right](\mathrm{BArF})_{4}$}

To assess the ability of the cage to act as an allosteric receptor, guest molecules that can be trapped by coordination to the zinc(II) porphyrins or stabilized in between their large $\pi$-electron rich core were considered. It must be noticed that cages $\mathbf{1}$ and $\mathbf{2}$ adopt a flattened conformation in a DCM $/ 10 \% \mathrm{MeOH}$ solution or even in solvents of higher polarity (DMSO, DMF). ${ }^{[78,79]}$ This compact form stabilized by $\pi-\pi$ interactions between the zinc(II) porphyrins was confirmed in the solid state with an X-ray crystallographic structure of cage 2. ${ }^{[78]}$ Complexes $\left[\mathrm{Ag}_{4} \mathrm{X}\right](\mathrm{BArF})_{4}(\mathbf{X}=\mathbf{1}$ or $\mathbf{2}$, $\mathrm{BArF}^{-}$: tetrakis[3,5-bis(trifluoromethyl)phenyl]borate)), soluble in DCM, were obtained quantitatively as reported. ${ }^{[79]}$ To characterize the cavity of the silver(I)-complexed cages several attempts of crystallization were made before single crystals suitable for X-ray analysis were obtained, by diffusion of cyclohexane into a solution of $\left[\mathrm{Ag}_{4} \mathbf{1}\right](\mathrm{BArF})_{4}$ in 1,2-dichloroethane. The X-ray structure revealed the cage structure with $c a$. two types of rectangular windows, sized ca. $4.5 \times 15 \AA$ and $6 \times 8 \AA$, resulting from the synanti-syn-anti disposition of the four silver(I)-triazolyl connectors in which each of the silver(I) ions lie in a coordination pocket formed by two triazolyl groups and a diethoxyethane linker (Figure 1).

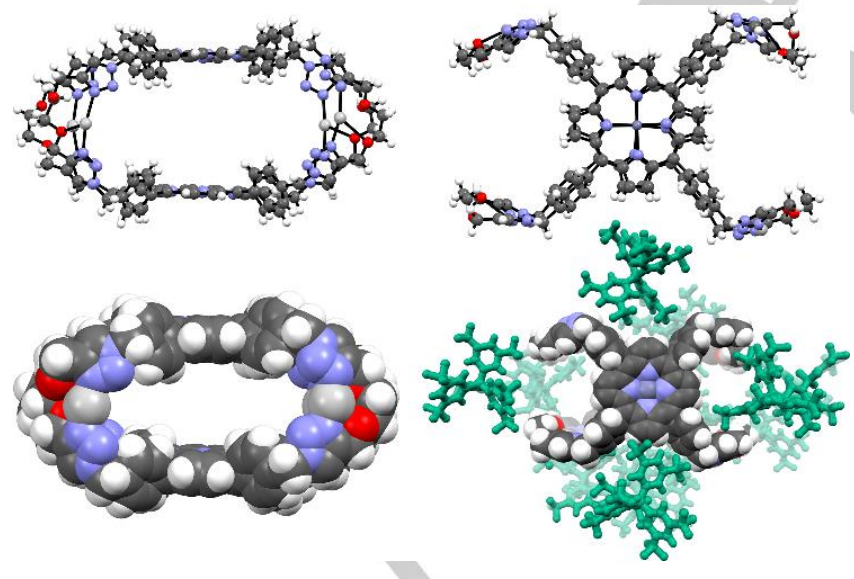

Figure 1. Crystal structure of the cage $\left[\mathrm{Ag}_{4} 1\right](\mathrm{BArF})_{4}$, ball-and-stick (top) and VDW (below) representations. The BArF ${ }^{-}$anions and the located solvent cyclohexanes are excluded for clarity for all except for the bottom right illustration which demonstrates the packing of the anions and solvent molecules (shown in green) at close proximities to the host cavity openings.

The $A g^{\prime}-\mathrm{N}$ bond lengths are similar to those observed in analogous silver $(\mathrm{I})$ complexes $^{[80]}$ whereas the distances of the
Ag'-O bonds are longer on average. This can be attributed to the inability of the diethoxyethane O-atoms to adopt optimal position around the silver(I) ion due to steric effects. The silver(I) ion complexation brings the two zinc(II) porphyrins in an eclipsed cofacial position with intramolecular $\mathrm{Zn} \cdots \mathrm{Zn}$ distance of $9.5 \AA$. Such arrangement leads to a well-defined cavity between the zinc(II) porphyrin moieties, with an approximate volume of $230 \AA^{3}$ (Figure 1 bottom, see $\mathrm{SI}$ for further discussion on the cavity volume).

\section{Allosteric control of pyrazine encapsulation}

The encapsulation of pyrazine in molecular cages $\mathbf{1}$ and $\mathbf{2}$ was studied at millimolar concentration by NMR spectroscopy. The reaction performed with 1 equivalent of pyrazine did not show evidence of encapsulation of this ligand in various solvents $\left(\mathrm{CH}_{2} \mathrm{Cl}_{2}, \mathrm{CHCl}_{3}\right.$, DMF or DMSO) even after sonication or prolonged heating. In apolar solvent, external binding of the ligand to the zinc(II) porphyrins led to insoluble oligomers (Figure S11). This result contrasts with the one obtained with DABCO that was encapsulated quantitatively in cages $\mathbf{1}$ and $\mathbf{2}$, in $\mathrm{CH}_{2} \mathrm{Cl}_{2}$ and $\mathrm{CH}_{2} \mathrm{Cl}_{2} / 10 \% \mathrm{MeOH}$, respectively. ${ }^{[78,79]}$

The complexation of pyrazine was therefore tested on silver(I)complexed cages $\left[\mathrm{Ag}_{4} \mathrm{X}\right](\mathrm{BArF}) 4(\mathbf{X}=\mathbf{1}$ or $\mathbf{2})$ in DCM. When 1 equivalent of pyrazine was added to the solution of the complex $\left[\mathrm{Ag}_{4} 1\right](\mathrm{BArF})_{4}$ in $\mathrm{CD}_{2} \mathrm{Cl}_{2}$, the singlet that accounts for its four protons experienced a huge upfield shift of $7.54 \mathrm{ppm}$ attributed to its inward coordination to the zinc(II) porphyrins (Figure 2). A NOESY spectrum showed cross-peaks of the pyrazine protons with the pyrrolic protons $\left(\mathrm{H}_{\text {pyr }}\right)$ of the porphyrins and with the protons of the phenyl rings that point inside the cavity $\left(\mathrm{H}_{\mathrm{o}}\right.$ in $)$ (Figure S4). These correlations attested the internal binding mode of the pyrazine to the silver(I)-complexed cage $\left[\mathrm{Ag}_{4} 1\right](\mathrm{BArF})_{4}$. Since the $\mathrm{Zn} \cdots \mathrm{Zn}$ distance $9.5 \AA$ is larger than the distance for a ditopic binding (ca. $7 \AA$ ), the guest was expected to be in fast exchange between the two zinc(II)-porphyrin coordination sites on the NMR timescale. A variable-temperature ${ }^{1} \mathrm{H}$ NMR experiment showed a sharpening and an upfield shift of the pyrazine signal upon lowering the temperature, in accordance with this hypothesis (Figure S12). ${ }^{1} \mathrm{H}$ DOSY spectrum supported the quantitative encapsulation of the pyrazine since the host and guest molecules had the same diffusion coefficient $330 \mu \mathrm{m}^{2} . \mathrm{s}^{-1}$ (Figure S8). UV-vis titration gave the best fit for the $1: 1$ binding model with an association constant $\log K_{a}=6.65 \pm 0.03$ (Figure S14). The pyrazine@ $\left[\mathrm{Ag}_{4} 1\right](\mathrm{BArF})_{4}$ complex was also detected at $\mathrm{m} / \mathrm{z}=2293.7599$ by cold-spray ionization mass-spectrometry (Figure S9). NMR experiments showed also evidence of the encapsulation of pyrazine in $\left[\mathrm{Ag}_{4} 2\right](\mathrm{BArF})_{4}$ (Figure S35-38). In this case, the diffusion coefficient of the pyrazine, $346 \mu \mathrm{m}^{2} . \mathrm{s}^{-1}$ and the one of the cage, $328 \mu \mathrm{m}^{2} . \mathrm{s}^{-1}$ were within the experimental errors of $5 \%$. 


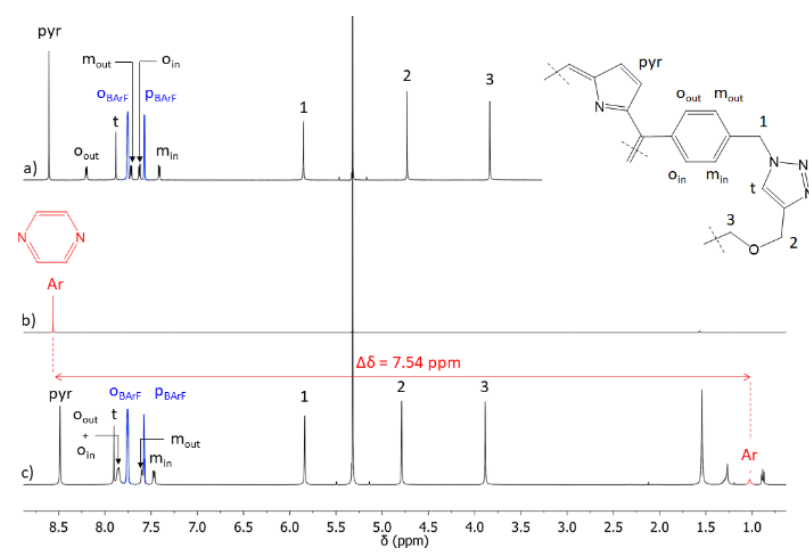

Figure 2. ${ }^{1} \mathrm{H}$ NMR $\left(400 \mathrm{MHz}, \mathrm{CD}_{2} \mathrm{Cl}_{2}, 298 \mathrm{~K}\right)$ a) $\left[\mathrm{Ag}_{4} 1\right](\mathrm{BArF})_{4}$, b) pyrazine and c) $\left[\mathrm{Ag}_{4} \mathbf{1}\right](\mathrm{BArF})_{4}$ with 1 equivalent pyrazine..

Binding silver(I) ions opens the structures of $\mathbf{1}$ and $\mathbf{2}$ and leads to $C_{4}$-symmetric complexes in solution with a face-to-face disposition of the porphyrins. Such preorganization enables the pyrazine to be readily inserted in the silver(I)-complexed hosts whereas pyrazine coordination does not overcome the $\pi$-stacking energy between the porphyrins in cages $\mathbf{1}$ and $\mathbf{2}$, and the entropic penalty of its inclusion. Indeed, pyrazine is a much weaker ligand $\left(\mathrm{p} K_{a 1}=-5.8 \text { and } \mathrm{p} K_{\mathrm{a} 2}=0.7\right)^{[81]}$ than DABCO $\left(\mathrm{p} K_{a 1}=2.9\right.$ and $\mathrm{p} K_{a 2}$ $=8.6)^{[82]}$ despite their similar sizes, $2.8 \AA$ and $2.7 \AA$, respectively. This explains why DABCO, as a stronger ligand, opens the cages upon binding without the help of the effector, silver(I) ion.

Silver (I) ions can be decoordinated using photons ${ }^{[64]}$ or chemically with a chloride salt. Upon addition of $\mathrm{NBu}_{4} \mathrm{Cl}$ to a solution of cage $\left[\mathrm{Ag}_{4} 1\right](\mathrm{BArF})_{4}$ including pyrazine, the cage and pyrazine signals became broad and progressively disappeared in accordance with the ejection of the ligand from the cage upon removal of silver(I) ions (Figure S10). The formation of insoluble oligomers by external binding of pyrazine to the cage was also observed when the binding was tested on the cage 1 (vide supra and Figure S11). This result shows that the positive allosteric guest binding triggered by silver(I) ions is a reversible on/off process.

Single crystals were grown by diffusion of cyclohexane into a 1,2dichloroethane solution the 1:1 host-guest pyrazine$\left[\mathrm{Ag}_{4} 1\right](\mathrm{BArF})_{4}$ complex. The $\mathrm{X}$-ray structure reveals a large conformational change of the silver(I)-triazolyl connectors from a syn-anti-syn-anti conformation observed for the guest free $\left[\mathrm{Ag}_{4} 1\right](\mathrm{BArF})_{4}$ to a syn-syn-syn-syn conformation and the presence of two pyrazines encapsulated in its cavity, each binding in a monotopic fashion to one zinc(II) porphyrin (Figure 3). The complexation of the two pyrazines into the cavity and the orientation of the Ag-triazolyl connectors modulate the conformation of the whole cage so that the $\mathrm{Zn}$-atoms are no longer on top of each other, since the two porphyrin planes show a ca. $2 \AA$ offset with respect to each other (Figure 3, top left). However, the distance between the porphyrin planes does not change more than $0.5 \AA$, which results in a slight reduction in the cavity size to ca. $200-210 \AA^{3}$. The volume of the pyrazine is 86 $\AA^{3}$ and thus the Rebek ${ }^{[83]}$ packing coefficient is $2 \times 86 / 205 \times 100$
$=84 \%$, i.e. substantially higher than the $55 \%$ for a noncoordinated guest. The encapsulation of two pyrazines contrasts with the encapsulation of one guest only in solution (vide supra). Upon addition of a second equivalent of pyrazine to a solution of pyrazine@[ $\left.\mathrm{Ag}_{4} \mathbf{1}\right](\mathrm{BArF})_{4}$, the variable temperature NMR data showed intermediate exchange binding at $273 \mathrm{~K}$ and slow exchange of the encapsulated guest with the free guest at $193 \mathrm{~K}$ (Figure S13). Clearly, in the solid state, the large size of the cavity, the $\mathrm{Zn}$-to-N binding energies and the steric fit (high packing coefficient) are the driving force for the "double" pyrazine complexation. This is supported by the fact that the two pyrazine guests will fill up the cavity fully with interplanar distance of 3.48 $\AA$, indicating $\pi-\pi$ interactions between the pyrazine guests. This result was reproducible, since the $\mathrm{X}$-ray analysis of another crystal obtained from another crystallization tube grown in the same crystallization conditions gave the same result.

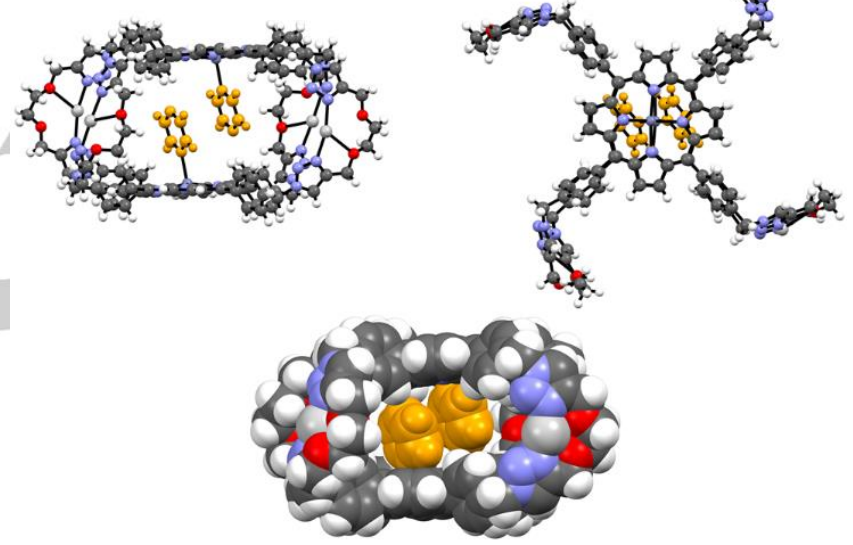

Figure 3. The crystal structure of (pyrazine) $)_{2} @\left[\mathrm{Ag}_{4} 1\right](\mathrm{BArF})_{4}$, ball-and-stick (top) and VDW (below) representations. The pyrazines are shown in orange color, the $\mathrm{BArF}^{-}$anions and disordered atoms are excluded for clarity.

\section{Allosteric control of NDI encapsulation}

The affinity of a m-acceptor NDI guest for the cages was also studied. This guest was not encapsulated in the flattened molecular cages $\mathbf{1}$ and $\mathbf{2}$ in DCM or DMF even upon prolonged heating. The ability of silver (I) ions to trigger its encapsulation was then investigated. When 1 equivalent of NDI was added to a solution of $\left[\mathrm{Ag}_{4} 1\right](\mathrm{BArF})_{4}$ in $\mathrm{DCM}$, all the guest protons were upfield shifted as seen on the ${ }^{1} \mathrm{H}$ NMR spectra (Figure 4). The most pronounced shifts were observed for the NDI aromatic protons $(0.54 \mathrm{ppm})$ in accordance with its stabilization between the two porphyrins. NOESY NMR spectrum (Figure S18) showed cross-peaks between the $\mathrm{CH}_{2}\left(\mathrm{H}_{\alpha}\right)$ of the NDI and both the pyrrolic protons $\left(\mathrm{H}_{\text {pyr }}\right)$ and phenyl protons $\left(\mathrm{H}_{\mathrm{o}}\right.$ in $)$ of the cages in agreement with the close proximity of the guest enclosed in the cage. ${ }^{1} \mathrm{H}$ DOSY experiments in DCM or DMF showed also the affinity of NDI for silver(I)-complexed cages. In both solvents, NDI had a lower diffusion coefficient than free NDI. ${ }^{1} \mathrm{H}$ NMR titration of $\left[\mathrm{Ag}_{4} \mathbf{1}\right](\mathrm{BArF})_{4}$ with $\mathrm{NDI}$ was performed in DCM to evaluate the strength of this interaction (Figure S24). Data were fitted to a 1:1 
stoichiometry and gave a binding constant $K_{a}=(95 \pm 20) \mathrm{M}^{-1}$. This encapsulation process is also reversible since upon addition of $\mathrm{NBu}_{4} \mathrm{Cl}$ and precipitation of $\mathrm{AgCl}$, the guest was quantitatively expelled from the cage (Figure S25).

The complexation of NDI with $\left[\mathrm{Ag}_{4} 1\right](\mathrm{BArF})_{4}$ and $\left[\mathrm{Ag}_{4} 2\right](\mathrm{BArF})_{4}$ was also detected using high resolution ESI mass-spectrometry (Figure S23, S45).

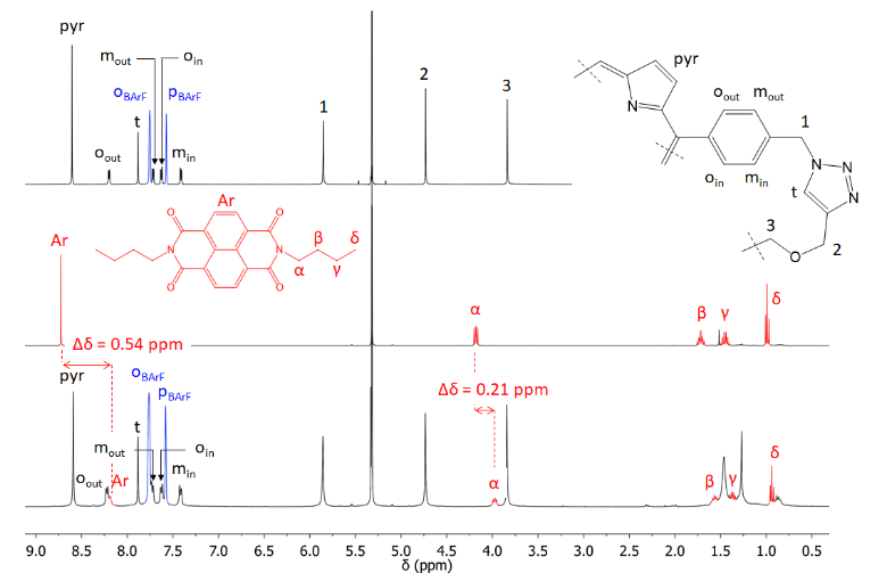

Figure 4. ${ }^{1} \mathrm{H}$ NMR (400 MHz, $\left.\mathrm{CD}_{2} \mathrm{Cl}_{2}, 298 \mathrm{~K}\right)$ a) $\left[\mathrm{Ag}_{4} 1\right](\mathrm{BArF})_{4}$, b) $\mathrm{NDI}$ and c) $\left[\mathrm{Ag}_{4} 1\right](\mathrm{BArF})_{4}$ with 1 equivalent of NDI.

\section{Conclusions}

The flexible cages 1 and 2 equipped with peripheral triazoles behave as on/off allosteric receptors as represented in Figure 5.

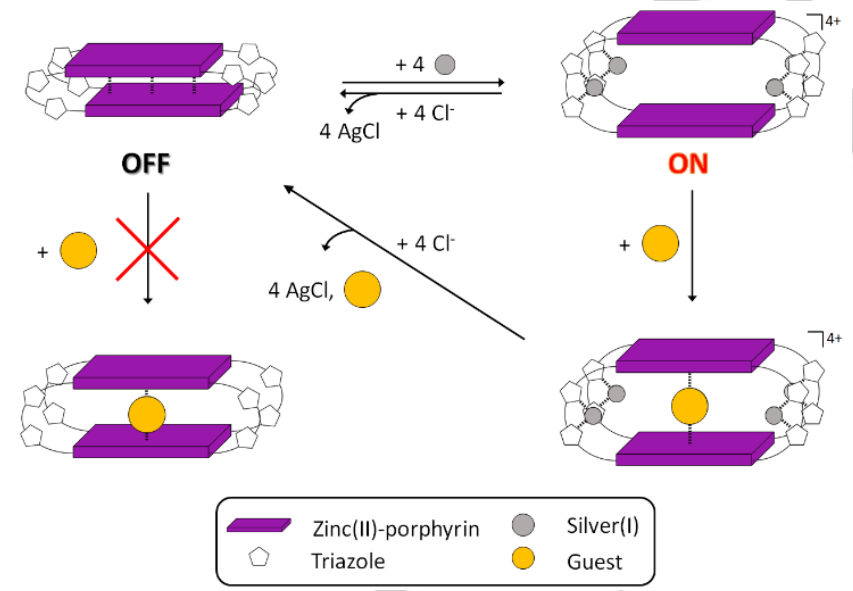

Figure 5. Schematic representation of the allosteric control of guest binding in flexible molecular cage receptors.

Guest binding inside these receptors is controlled by the reversible coordination/decoordination of an effector, silver(I) ions. Upon binding, silver(I) ions trigger a large conformational change of the cages that opens the cavity, as shown on the crystallographic structure obtained for the silver(I)-complexed cage 1. Such modification activates the receptors that are able to bind in their open form two different kinds of guest molecules inside the cavity, a pyrazine ligand or a $\pi$-acceptor NDI molecule. This reversible on/off control of guest binding inside such structures opens the way to develop highly selective molecular sensors but also stimuli-responsive nanoreactors able to fine-tune the reactivity performed in their hollow structures upon addition of a suitable effector.

\section{Acknowledgements}

The International Center for Frontier Research in Chemistry, icFRC (www.icfrc.fr), and the LabEx-CSC are gratefully acknowledged for Ph.D. fellowship to L.K. The Ministry of Education and Research is acknowledged for a Ph.D. fellowship to R.D. We also thank the ANR Agency for the funding of the project ANR 14-CE06-0010 "Switchable cages". K.R. gratefully acknowledges the financial support from the University of Jyväskylä, and A.P from the Academy of Finland (project no. 315911). VH is grateful to $\mathrm{Dr}$ J.-C. Chambron for helpful discussions

\section{Conflicts of interest}

The authors declare no competing financial interest.

Keywords: supramolecular chemistry $\cdot$ allosteric control $\bullet$ hostguest systems $\bullet$ cage compounds $\bullet$ porphyrin

[1] J.-P. Changeux, A. Christopoulos, Cell 2016, 166, 1084-1102.

[2] P. Tompa, Chem. Rev. 2014, 114, 6715-6732.

[3] A. Peracchi, A. Mozzarelli, Biochim. Biophys. Acta BBA - Proteins Proteomics 2011, 1814, 922-933.

J. H. Jordan, B. C. Gibb, Chem. Soc. Rev. 2015, 44, 547-585.

J. Rebek Jr, Acc. Chem. Res. 2009, 42, 1660-1668.

R. Chakrabarty, P. S. Mukherjee, P. J. Stang, Chem. Rev. 2011, 111, 6810-6918.

[7] K. Harris, D. Fujita, M. Fujita, Chem. Commun. 2013, 49, 67036712.

[8] S. Mukherjee, P. S. Mukherjee, Chem Commun 2014, 50, 22392248.

[9] D. Fiedler, D. H. Leung, R. G. Bergman, K. N. Raymond, Acc Chem. Res. 2005, 38, 349-358.

[10] M. Yoshizawa, J. K. Klosterman, M. Fujita, Angew. Chem. Int. Ed 2009, 48, 3418-3438.

[11] S. H. A. M. Leenders, R. Gramage-Doria, B. de Bruin, J. N. H. Reek, Chem. Soc. Rev. 2015, 44, 433-448.

[12] J.-N. Rebilly, B. Colasson, O. Bistri, D. Over, O. Reinaud, Chem. Soc. Rev. 2015, 44, 467-489.

[13] S. Zarra, D. M. Wood, D. A. Roberts, J. R. Nitschke, Chem. Soc. Rev. 2015, 44, 419-432.

[14] D. S. Kim, J. L. Sessler, Chem. Soc. Rev. 2015, 44, 532-546.

[15] K. I. Assaf, W. M. Nau, Chem. Soc. Rev. 2015, 44, 394-418.

[16] M. Otte, ACS Catal. 2016, 6, 6491-6510.

[17] M. Raynal, P. Ballester, A. Vidal-Ferran, P. W. N. M. van Leeuwen, Chem. Soc. Rev. 2014, 43, 1734-1787.

[18] T. S. Koblenz, J. Wassenaar, J. N. H. Reek, Chem. Soc. Rev. 2008, 37, 247-262.

[19] C. J. Brown, F. D. Toste, R. G. Bergman, K. N. Raymond, Chem. Rev. 2015, 115, 3012-3035.

[20] Y. Ueda, H. Ito, D. Fujita, M. Fujita, J. Am. Chem. Soc. 2017, 139, $6090-6093$.

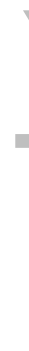


[21] T. M. Bräuer, Q. Zhang, K. Tiefenbacher, J. Am. Chem. Soc. 2017, 139, 17500-17507.

[22] P. Zhang, J. Meijide Suárez, T. Driant, E. Derat, Y. Zhang, M. Ménand, S. Roland, M. Sollogoub, Angew. Chem. 2017, 129, 10961-10965.

[23] J. Jiao, C. Tan, Z. Li, Y. Liu, X. Han, Y. Cui, J. Am. Chem. Soc. 2018, 140, 2251-2259.

[24] L. Zhao, X. Jing, X. Li, X. Guo, L. Zeng, C. He, C. Duan, Coord. Chem. Rev. 2017.

[25] H.-J. Schneider, Org. Biomol. Chem. 2016, 14, 7994-8001.

[26] L. Kovbasyuk, R. Krämer, Chem. Rev. 2004, 104, 3161-3188.

[27] C. Kremer, A. Lützen, Chem. - Eur. J. 2013, 19, 6162-6196.

[28] S. Shinkai, M. Ikeda, A. Sugasaki, M. Takeuchi, Acc. Chem. Res. 2001, 34, 494-503.

[29] A. M. Lifschitz, M. S. Rosen, C. M. McGuirk, C. A. Mirkin, J. Am. Chem. Soc. 2015, 137, 7252-7261.

[30] M. J. Wiester, P. A. Ulmann, C. A. Mirkin, Angew. Chem. Int. Ed. 2011, 50, 114-137.

[31] L. Yang, X. Jing, B. An, C. He, Y. Yang, C. Duan, Chem. Sci. 2018, 9, 1050-1057.

[32] X. Chen, T. M. Gerger, C. Räuber, G. Raabe, C. Göb, I. M. Oppel, M. Albrecht, Angew. Chem. Int. Ed. 2018, 57, 1181711820.

[33] N. Branda, R. M. Grotzfeld, C. Valdes, J. J. Rebek Jr, J. Am. Chem. Soc. 1995, 117, 85-88.

[34] S. Löffler, J. Lübben, L. Krause, D. Stalke, B. Dittrich, G. H. Clever, J. Am. Chem. Soc. 2015, 137, 1060-1063.

[35] J. Mendez-Arroyo, J. Barroso-Flores, A. M. Lifschitz, A. A Sarjeant, C. L. Stern, C. A. Mirkin, J. Am. Chem. Soc. 2014, 136, 10340-10348.

[36] S. Rieth, B.-Y. Wang, X. Bao, J. D. Badjić, Org. Lett. 2009, 11, 2495-2498.

[37] D. Preston, A. Fox-Charles, W. K. C. Lo, J. D. Crowley, Chem. Commun. 2015, 51, 9042-9045.

[38] N. Kishi, M. Akita, M. Yoshizawa, Angew. Chem. Int. Ed. 2014, 53, 3604-3607.

[39] D. Ajami, J. Rebek Jr, J. Am. Chem. Soc. 2006, 128, 1503815039.

[40] T. Gottschalk, B. Jaun, F. Diederich, Angew. Chem. Int. Ed. 2007, 46, 260-264.

[41] S. Hiraoka, K. Harano, M. Shiro, M. Shionoya, Angew. Chem. Int. Ed. 2005, 44, 2727-2731.

[42] W. J. Ramsay, J. R. Nitschke, J. Am. Chem. Soc. 2014, 136, 7038-7043.

[43] C. M. Davis, J. M. Lim, K. R. Larsen, D. S. Kim, Y. M. Sung, D. M. Lyons, V. M. Lynch, K. A. Nielsen, J. O. Jeppesen, D. Kim, et al., J. Am. Chem. Soc. 2014, 136, 10410-10417.

[44] S. Akine, M. Miyashita, T. Nabeshima, J. Am. Chem. Soc. 2017, 139, 4631-4634.

[45] Y.-L. Ma, H. Ke, A. Valkonen, K. Rissanen, W. Jiang, Angew. Chem. Int. Ed. 2018, 57, 709-713.

[46] D. Zhang, J. R. Cochrane, S. Di Pietro, L. Guy, H. Gornitzka, J.P. Dutasta, A. Martinez, Chem. - Eur. J. 2017, 23, 6495-6498.

[47] V. Marcos, A. J. Stephens, J. Jaramillo-Garcia, A. L. Nussbaumer, S. L. Woltering, A. Valero, J.-F. Lemonnier, I. J. Vitorica-Yrezabal, D. A. Leigh, Science 2016, 352, 1555-1559.

[48] P. Thordarson, E. J. A. Bijsterveld, J. A. A. W. Elemans, P. Kasák, R. J. M. Nolte, A. E. Rowan, J. Am. Chem. Soc. 2003, $125,1186-1187$.

[49] V. Croué, S. Goeb, G. Szalóki, M. Allain, M. Sallé, Angew. Chem. Int. Ed. 2016, 55, 1746-1750.

[50] S. Stojanović, D. A. Turner, A. I. Share, A. H. Flood, C. M. Hadad, J. D. Badjić, Chem. Commun. 2012, 48, 4429-4431.

[51] I. Pochorovski, F. Diederich, Acc. Chem. Res. 2014, 47, 20962105.
[52] M. Han, R. Michel, B. He, Y.-S. Chen, D. Stalke, M. John, G. H. Clever, Angew. Chem. Int. Ed. 2013, 52, 1319-1323.

[53] F. Corbellini, R. M. A. Knegtel, P. D. J. Grootenhuis, M. CregoCalama, D. N. Reinhoudt, Chem. - Eur. J. 2005, 11, 298-307.

[54] E. Busseron, J. Lux, M. Degardin, J. Rebek Jr, Chem. Commun. 2013, 49, 4842-4844.

[55] O. B. Berryman, A. C. Sather, A. Lledó, J. Rebek Jr, Angew. Chem. Int. Ed. 2011, 50, 9400-9403.

[56] M. Liu, X. Yan, M. Hu, X. Chen, M. Zhang, B. Zheng, X. Hu, S. Shao, F. Huang, Org. Lett. 2010, 12, 2558-2561.

[57] R. S. Stoll, S. Hecht, Angew. Chem. Int. Ed. 2010, 49, 50545075.

[58] N. Kishi, M. Akita, M. Kamiya, S. Hayashi, H.-F. Hsu, M. Yoshizawa, J. Am. Chem. Soc. 2013, 135, 12976-12979.

[59] S. Durot, J. Taesch, V. Heitz, Chem. Rev. 2014, 114, 8542-8578.

[60] C. García-Simón, R. Gramage-Doria, S. Raoufmoghaddam, T. Parella, M. Costas, X. Ribas, J. N. H. Reek, J. Am. Chem. Soc. 2015, 137, 2680-2687.

[61] P. F. Kuijpers, M. Otte, M. Dürr, I. Ivanović-Burmazović, J. N. H. Reek, B. de Bruin, ACS Catal. 2016, 6, 3106-3112.

[62] C. Colomban, C. Fuertes-Espinosa, S. Goeb, M. Sallé, M. Costas, L. Blancafort, X. Ribas, Chem. - Eur. J. 2018, 24, 1-12.

[63] W. Brenner, T. K. Ronson, J. R. Nitschke, J. Am. Chem. Soc. 2017, 139, 75-78.

[64] H. Sato, K. Tashiro, H. Shinmori, A. Osuka, Y. Murata, K. Komatsu, T. Aida, J. Am. Chem. Soc. 2005, 127, 13086-13087.

[65] N. P. E. Barry, O. Zava, P. J. Dyson, B. Therrien, Aust. J. Chem. 2010, 63, 1529-1537.

[66] A. N. Oldacre, A. E. Friedman, T. R. Cook, J. Am. Chem. Soc. 2017, 139, 1424-1427.

[67] S. K. Samanta, A. Rana, M. Schmittel, Angew. Chem. Int. Ed. 2016, 55, 2267-2272.

[68] P. T. Smith, B. P. Benke, Z. Cao, Y. Kim, E. M. Nichols, K. Kim C. J. Chang, Angew. Chem. Int. Ed. 2018, 57, 9684-9688.

[69] C. Zhang, Q. Wang, H. Long, W. Zhang, J. Am. Chem. Soc. 2011, 133, 20995-21001.

[70] F. Hajjaj, K. Tashiro, H. Nikawa, N. Mizorogi, T. Akasaka, S Nagase, K. Furukawa, T. Kato, T. Aida, J. Am. Chem. Soc. 2011, 133, 9290-9292.

[71] J. Zhang, X. Zheng, R. Jiang, Y. Yu, Y. Li, H. Liu, Q. Li, Z. Shuai, Y. Li, RSC Adv. 2014, 4, 27389-27392.

[72] B. Zhu, H. Chen, W. Lin, Y. Ye, J. Wu, S. Li, J. Am. Chem. Soc. 2014, 136, 15126-15129.

[73] S. K. Samanta, M. Schmittel, Org. Biomol. Chem. 2013, 11, 3108-3115.

[74] F. J. Rizzuto, W. J. Ramsay, J. R. Nitschke, J. Am. Chem. Soc. 2018, 140, 11502-11509.

[75] Y. Shi, K. Cai, H. Xiao, Z. Liu, J. Zhou, D. Shen, Y. Qiu, Q.-H Guo, C. Stern, M. R. Wasielewski, et al., J. Am. Chem. Soc. 2018, 140, 13835-13842.

[76] P. Ballester, M. Claudel, S. Durot, L. Kocher, L. Schoepff, V. Heitz, Chem. - Eur. J. 2015, 21, 15339-15348.

[77] J. Taesch, V. Heitz, F. Topić, K. Rissanen, Chem. Commun. 2012, 48, 5118-5120.

[78] L. Kocher, S. Durot, V. Heitz, Chem. Commun. 2015, 51, 1318113184.

[79] L. Schoepff, L. Kocher, S. Durot, V. Heitz, J. Org. Chem. 2017, $82,5845-5851$.

[80] M. L. Gower, J. D. Crowley, Dalton Trans. 2010, 39, 2371-2378.

[81] A. S. Chia, R. F. J. Trimble, J. Phys. Chem. 1961, 65, 863-866.

[82] J. Rumble, CRC Handbook of Chemistry and Physics, Taylor \& Francis Group, 2018

[83] S. Mecozzi, J. Rebek Jr, Chem. - Eur. J. 1998, 4, 1016-1022. 


\section{WILEY-VCH}

\section{FULL PAPER}

Entry for the Table of Contents (Please choose one layout)

Layout 2:

\section{FULL PAPER}

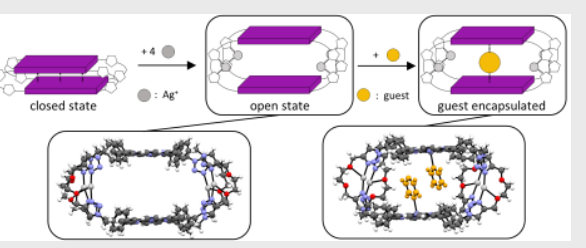

Ryan Djemili, [a] Lucas Kocher, ${ }^{[a]}$ Stéphanie Durot, ${ }^{[a]}$ Anssi Peuronen, ${ }^{[b]}$ Kari Rissanen, ${ }^{*[c]}$ and Valérie Heitz ${ }^{*[a]}$

Page No. - Page No.

Positive Allosteric Control of Guests Encapsulation by Metal Binding to Covalent Porphyrin Cages

Allosteric receptor: two flexible covalent cages have shown an on/off encapsulation mechanism triggered by significant conformational changes upon silver(I) coordination to the peripheral binding sites. In addition, the X-ray structure of the silver(I)-bound receptor and the one with pyrazine as guest confirmed the large cavity size of the receptor.

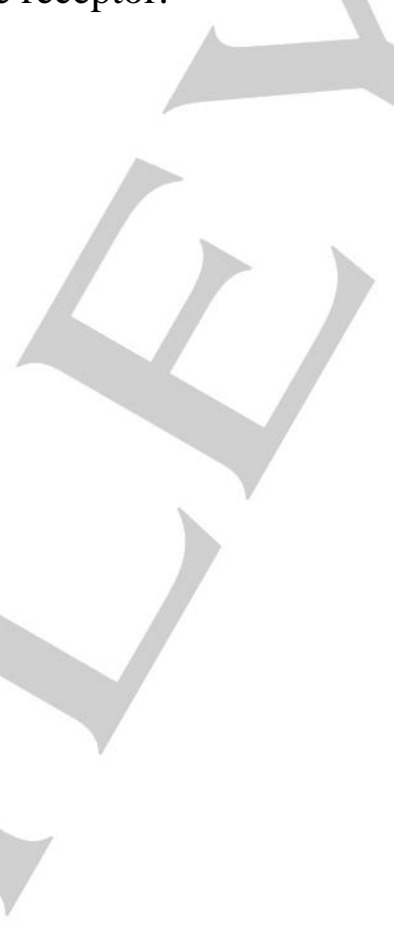

